\title{
Phenological maps of Europe
}

\author{
Thomas Rötzer*, Frank-M. Chmielewski \\ Institute of Crop Sciences, Subdivision of Agricultural Meteorology, College of Agriculture and Horticulture, \\ Humboldt-University of Berlin, Albrecht-Thaer-Weg 5, 14195 Berlin-Dahlem, Germany
}

\begin{abstract}
The geographical distribution of the timings of phenological phases is a precondition for detecting regional trends of the annual timings of phenological phases and finding their relationships to climate changes. Therefore phenological maps of Europe have been computed showing long-term means, trends and annual timings of extreme years. In this article maps of the beginning, the end and the length of the growing season as means over the years 1961-1998 as well as for the warm year 1990 are presented. Strong dependences on altitude, longitude and latitude were computed both for single phenological phases and the beginning and end of the growing season. The goodness of fit for the regression equation was between $32 \%$ for the end and $83 \%$ for the beginning of growing season. The results were consistent with those of similar investigations.
\end{abstract}

KEY WORDS: Phenology $\cdot$ Maps · Growing season · GIS · Europe Resale or republication not permitted without written consent of the publisher

\section{INTRODUCTION}

The annual course of the seasons is reflected by the regularity of the starting dates of phenological phases of plants, such as the unfolding of leaves or the beginning of leaf fall. Phenological maps show the geographical distribution of the annual timings of phenophases, thus reflecting the dynamics of seasons.

The use of phenological maps is manifold: They form the base for maps showing the climatological suitability for growing crops, the risk of frost damage for fruit trees and the climatic risks of plant diseases and pests affecting crops (Rötzer et al. 1997). Calculating the water-balance of crops (Rötzer et al. 1997), investigating the relationship between climate and vegetation (Walkovszky 1998) and calibrating remotely sensed data (Schwarz \& Reed 1999) are further applications of phenological maps.

Phenological maps have previously been presented by Lieth \& Radford (1971), showing the beginning of flowering of Cornus florida, and by Chmielewski (1996), showing the leaf unfolding of Betula pubescens. They are part of nearly every climatic atlas, for

*E-mail: thomasroetzer@web.de example, the climatic atlas of Bavaria or NordrheinWestphalen. One of the first phenological maps of Europe was created by Schnelle (1955), who founded the International Phenological Gardens (IPGs) in 1957. Data have been collected in these IPGs for over $40 \mathrm{yr}$, and now a new kind of phenological map, based on a homogenous and proofed data set, can be made.

The aim of this study was to map the annual timings of phenological phases for long-term means and for extreme (e.g. warm) years. Maps showing the beginning, the end and the length of the growing season were computed as well. For all seasons the dependences of phenophases on geography were detected. The phenological maps made for Europe form the basis for investigations concerning the relationships between phenology and climate variability (Chmielewski \& Rötzer 2001).

\section{DATA AND METHODS}

The phenological maps of Europe are based on observations in the IPGs. In all the gardens of this network, up to 23 species of only vegetatively propagated trees and shrubs were planted. Ranging across $28^{\circ}$ latitude, from Scandinavia to Macedonia, and across 
$37^{\circ}$ longitude, from Ireland to Finland in the north and from Portugal to Macedonia in the south, the IPGs cover wide regions of Europe (Chmielewski 1996). From the establishment of the first garden in 1959 until 1998, about 60000 phenological data measurements have been collected in up to 66 gardens.

Before the phenological phases could be mapped, a validity check of all the observation data had to be done. All observations differing from the stations' means for more than $30 \mathrm{~d}$ were selected and checked. After the observers' remarks had been checked, the selected data were compared with the written records and with the same phenophases of the nearest stations and natural regions. In addition, the data were compared to the observations of the pre- and postphenophases as well as to similar terminated phenophases of the same stations.

Gaps in the time series were filled by using linear regression models with 1 independent parameter (= regressor). Regressors were either the same phenophase of the nearest station, the same phenophase of the natural region (Chmielewski \& Rötzer 2001), the pre- or post-phenophase at the same station or a similar terminated phenophase at the same station. For the calculation of a missing value the best regression model with regard to the coefficient of correlation was chosen. Missing values were only calculated if the correlation coefficient was higher than 0.70 .

The annual timing of phenophases is influenced mainly by air temperature. In spring the temperature across Europe decreases from south to north and from the maritime regions in West Europe to the continental regions in East Europe. With increasing altitude, the average air temperature decreases $0.65^{\circ} \mathrm{C}$ per $100 \mathrm{~m}$. Thus altitude, latitude and longitude provide the possibility of mapping the beginning of phenological phases by using multiple regression analysis.

The relationships between the annual timing of a phenological phase and altitude, latitude and longitude could be determined using the observations of the IPGs. By means of the resulting equation, the beginning of a phenological phase can be calculated for any given location of the map within the region of the network:

$$
p p(x, y, z)=c+a_{x} \cdot x+a_{y} \cdot y+a_{z} \cdot z
$$

where $p p(x, y, z)$ is the starting date of the phenological phase at altitude $z$, longitude $x$ and latitude $y, C$ is a constant and $a_{x}, a_{y}$ and $a_{z}$ are regression coefficients.

Eq. (1) computes the beginning of a phenological phase depending on the regressors altitude, longitude and latitude. The residual received from the difference between the observation at the IPG and the result of Eq. (1) includes the error as well as other unknown influencing factors. These are, for example, the plant conditions, the plant age and the micro-climate of the location, which shows strong relationships to exposure, inclination or the surroundings.

However, as the standard errors of the regression equations range from 2.8 to $8.2 \mathrm{~d}$ (Table 1), altitude, longitude and latitude are the main influencing factors. Nevertheless the standard error has to be regarded when the classification for the starting dates of a map is made.

By using a digital elevation model with a horizontal grid spacing of 30 arc-seconds (approximately $1 \mathrm{~km}$ )

Table 1. Shift of the beginning of selected phenophases with altitude $\left(a_{z}\right)$, longitude $\left(a_{x}\right)$ and latitude $\left(a_{y}\right)$. The results of the multiple regression analysis are derived from the means of the period 1961-1998. Mean: average annual timing for Europe 1961-1998 (JD: Julian day); n: number of IPGs; $C$ : constant of the regression equation; $\mathrm{r}^{2}$ : goodness of fit; SE: standard error; p: error probability. Phases: $\mathrm{BE}$, beginning; $\mathrm{B}$, beginning of flowering; $\mathrm{BO}$, leaf unfolding; $\mathrm{M}$, mayshoot; $\mathrm{F}$, first ripe fruits; $\mathrm{E}$, end; $\mathrm{BF}$, beginning of leaf fall. ${ }^{* * *} \mathrm{p}<0.001,{ }^{* *} \mathrm{p}<0.01 ;{ }^{*} \mathrm{p}<0.05$

\begin{tabular}{|c|c|c|c|c|c|c|c|c|c|c|}
\hline Plant & Phase & $\begin{array}{l}\text { Mean } \\
\text { (JD) }\end{array}$ & $\mathrm{n}$ & C & $\begin{array}{c}a_{z} \\
(\mathrm{~d} / 100 \mathrm{~m})\end{array}$ & $\begin{array}{c}a_{x} \\
(\mathrm{~d} / 100 \mathrm{~km})\end{array}$ & $\begin{array}{c}a_{y} \\
(\mathrm{~d} / 100 \mathrm{~km})\end{array}$ & $\begin{array}{l}\mathrm{r}^{2} \\
\%\end{array}$ & $\begin{array}{l}\text { SE } \\
\text { (d) }\end{array}$ & $\mathrm{p}$ \\
\hline Salix smithiana (Smith's willow) & B & 85 & 46 & -78.7 & 1.2 & 1.6 & 2.6 & 90 & 4.6 & *** \\
\hline Ribes alpinum (mountain currant) & $\mathrm{BO}$ & 101 & 43 & -55.1 & 3.5 & 0.0 & 2.6 & 79 & 7.4 & *** \\
\hline Growing season & $\mathrm{BE}$ & 111 & 37 & -32.6 & 3.1 & 0.5 & 2.3 & 83 & 5.2 & $* * *$ \\
\hline Betula pubescens (downy birch) & $\mathrm{BO}$ & 113 & 47 & -16.0 & 2.8 & 0.7 & 2.1 & 91 & 3.5 & *** \\
\hline Prunus avium 'B' (wild cherry) & $\mathrm{B}$ & 116 & 34 & -37.8 & 2.9 & 0.7 & 2.5 & 93 & 3.5 & *** \\
\hline Picea abies 'F' (Norway spruce) & M & 133 & 49 & 3.9 & 3.1 & 0.4 & 2.0 & 81 & 6.4 & *** \\
\hline Pinus silvestris (Scotch pine) & M & 133 & 38 & -20.9 & 2.6 & 0.4 & 2.6 & 87 & 5.6 & *** \\
\hline Robinia pseudoacacia (locust) & B & 147 & 18 & -55.2 & 4.6 & 0.5 & 3.5 & 97 & 2.8 & *** \\
\hline Sambucus nigra (common elder) & B & 154 & 15 & -6.7 & 3.4 & 0.0 & 2.8 & 84 & 4.5 & *** \\
\hline Prunus avium 'B' (wild cherry) & $\mathrm{F}$ & 181 & 17 & -0.3 & 3.7 & 0.0 & 3.2 & 86 & 5.4 & *** \\
\hline Sambucus nigra (common elder) & $\mathrm{F}$ & 240 & 12 & 42.8 & 2.9 & 0.0 & 3.6 & 52 & 7.5 & ${ }^{*}$ \\
\hline Ribes alpinum (mountain currant) & $\mathrm{BF}$ & 298 & 21 & 364.4 & -1.6 & -0.8 & -1.0 & 42 & 8.2 & ** \\
\hline Growing season & $\mathrm{E}$ & 303 & 29 & 310.6 & -1.0 & -0.2 & -0.1 & 32 & 6.5 & $* *$ \\
\hline Salix smithiana (Smith's willow) & $\mathrm{BF}$ & 308 & 25 & 267.4 & 0.0 & -0.4 & 0.8 & 46 & 4.4 & *** \\
\hline
\end{tabular}


and Eq. (1), phenological maps showing means, trends and starting dates of extreme years as well as maps of the beginning, the end and the length of the growing season were computed.

For a clearer representation, national borders, cities and rivers have been added to the maps.

\section{RESULTS}

In Table 1 the results of the regression analysis for different phenological phases are listed. They are sorted according to their annual timings.

With the exception of the phenophase 'first ripe fruit' of Sambucus nigra, all regression equations were highly significant $(p<0.01)$. The goodness of fit $r^{2}$ was obtained for spring and summer phenophases with values between $79 \%$ (leaf unfolding [BO] Ribes alpinum) and 97\% (beginning of flowering [B] Robinia pseudoacacia), while for late summer and autumn phenophases the goodness of fit was smaller, e.g. the leaf-fall of $R$. alpinum with $42 \%$ ( $p<0.01)$.

Almost all phenological phases of Table 1 show a dependence on latitude and altitude (exception: leaf fall [BF] Salix smithiana), whereas longitude is a significant regressor for only a couple of phenological phases: spring phenophases start later from west to east by 0.4 to $1.6 \mathrm{~d}$ per $100 \mathrm{~km}$, summer phenophases show no change and autumn phenophases start earlier from west to east with up to $0.8 \mathrm{~d}$ per $100 \mathrm{~km}$.

Similar values for the seasons can be found for altitude and latitude: both show strong dependences in spring and summer, which means a later start to the phenological phases with increasing altitude and latitude, and less or no dependences in autumn. For example, leaf-fall of Ribes alpinum in autumn starts $1.6 \mathrm{~d}$ earlier per $100 \mathrm{~m}$ greater altitude and $1.0 \mathrm{~d}$ earlier per $100 \mathrm{~km}$ from south to north, whereas for the leaf unfolding of the same species in spring stronger dependencies were found (altitude: $3.5 \mathrm{~d}$ per $100 \mathrm{~m}$; latitude: $2.6 \mathrm{~d}$ per $100 \mathrm{~km}$ from south to north).

To map the beginning, the end and the length of the growing season, indicator phases have to be defined. The beginning of the growing season was represented by the average date of leaf unfolding of Betula pubescens, Prunus avium, Sorbus aucuparia and Ribes alpinum. For the end of the growing season the average dates of leaf fall of B. pubescens, P. avium, Salix smithianta and $R$. alpinum were used. The difference between the end and the beginning of growing season was defined as the length of growing season. These phenophases were chosen because long time series can be provided by most IPGs. Furthermore, most vegetation becomes green and finishes growing in this period.
The dependences of the beginning and end of the growing season on altitude, longitude and latitudeaveraged over the years 1961-1998-can be derived from the regression coefficients averaged over the indicator phases. Thus the beginning of the growing season starts $3.1 \mathrm{~d}$ later per $100 \mathrm{~m}$ altitude, $0.5 \mathrm{~d}$ later per $100 \mathrm{~km}$ from west to east and $2.3 \mathrm{~d}$ later per $100 \mathrm{~km}$ from south to north $\left(\mathrm{r}^{2}=83 \%\right.$ with $\left.\mathrm{p}<0.001\right)$. Showing a goodness of fit of $32 \%(p<0.02)$, the growing season ends earlier with increasing altitude $(-1 \mathrm{~d}$ per $100 \mathrm{~m})$, increasing longitude $(-0.2 \mathrm{~d}$ per $100 \mathrm{~km})$ and latitude $(-0.1 \mathrm{~d}$ per $100 \mathrm{~km})$. Consequently the length of the growing season shortens $4.1 \mathrm{~d}$ per $100 \mathrm{~m}$ greater altitude, $0.7 \mathrm{~d}$ per $100 \mathrm{~km}$ from west to east and $2.4 \mathrm{~d}$ per $100 \mathrm{~km}$ from south to north.

Averaged over the years 1961-1998, the growing season starts in most regions of Europe between April 10 and 25 (Fig. 1). Whereas the British Isles with the exception of Scotland, Belgium, The Netherlands, the northern part of France as well as Hungary, Croatia and the former Republic of Yugoslavia show a beginning of growing season between April 5 and 15, a beginning before April 5 was calculated for southern France, northern Portugal and Spain and for most of the coastal regions of the Mediterranean Sea. A late beginning of the growing season between April 15 and 25 can be seen in most parts of Denmark, Germany, the Czech Republic and Poland. The growing season starts-averaged over the years-after April 25 in Scandinavia and in the Baltic Sea region.

In mountainous regions such as the Alps or the Dalmatian Mountains, great differences in the beginning of growing season can be seen: While alpine valleys often show a beginning of growing season before April 15, at high altitudes (above about $1500 \mathrm{~m}$ ) the growing season starts nearly 4 wk later. The latest beginning, after May 30, is observed in the highlands of Norway and north of the Arctic Circle.

The end of the growing season (Fig. 2) does not have the broad range of annual timings as the beginning of the growing season does. While in eastern Europe, most parts of Scandinavia, southern Germany, Switzerland, Austria and the Czech Republic the growing season ends between October 25 and 30, the western part of Europe, northern Germany, Hungary and southern Europe show slightly later dates between October 30 and November 4. At high altitudes such as the Alps, the Carpathian Mountains, the Dalmatian Mountains and the Scandinavian Mountains the end of the growing season can be observed before October 25 .

As the end of the growing season lies within a small spectrum for all of Europe, the length of the growing season mainly depends on the beginning. The longest growing seasons, with over $220 \mathrm{~d}$, can be found in the southern part of France and in the 


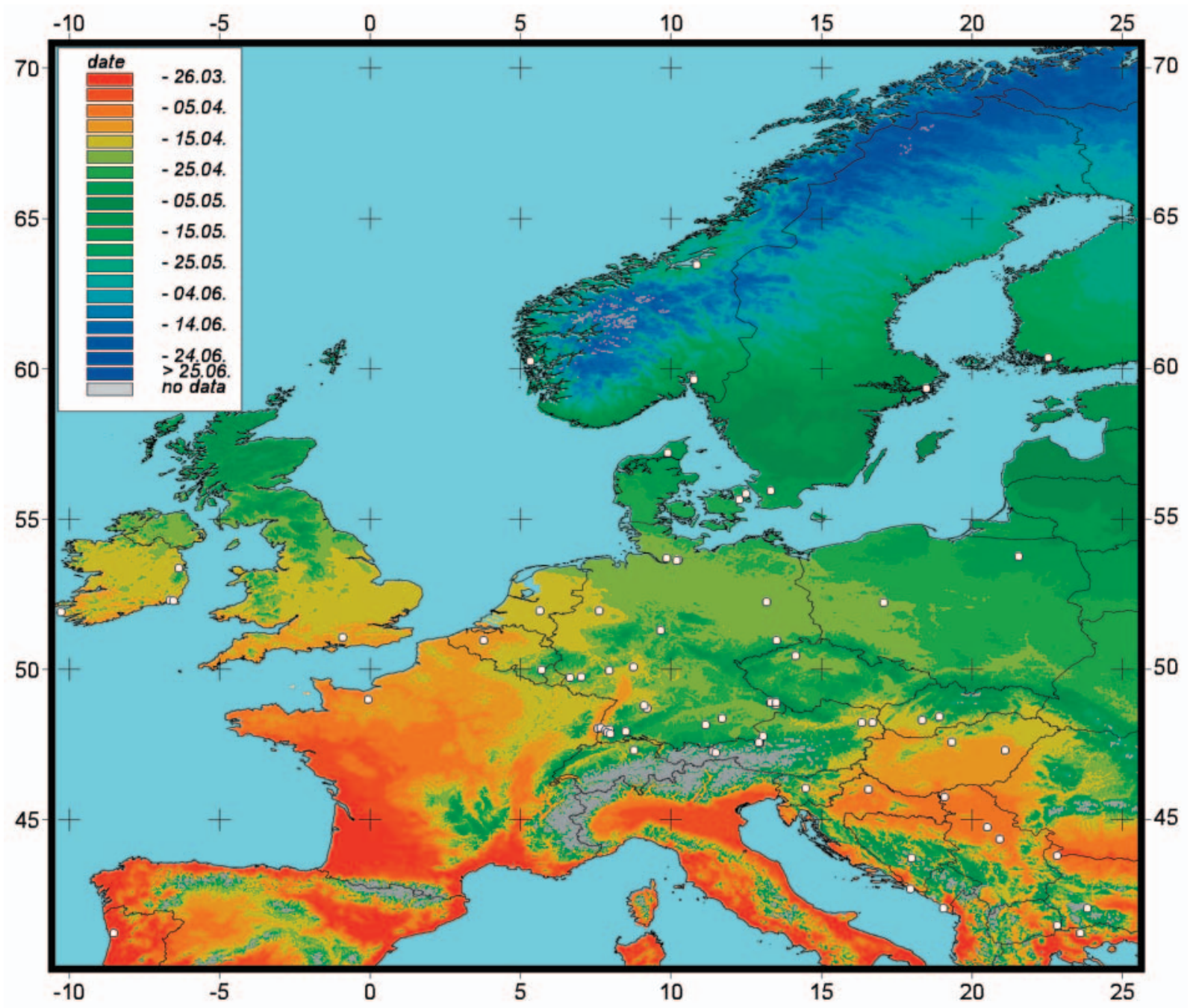

Fig. 1. Average beginning of the growing season in Europe for the period 1961-1998

coastal regions of southern Europe (Fig. 3). In large parts of Ireland, southern England, The Netherlands and in Belgium, and most parts of France, Hungary and southern Europe, minus the mountainous regions, the growing season lasts between 200 and $220 \mathrm{~d}$. In Scotland, Denmark, most regions of Germany, Switzerland, Austria, the Czech Republic, Slovenia and Poland, and in the southern part of Sweden, the growing season lasts less than $200 \mathrm{~d}$ but more than 180 d. Shorter growing seasons, with less than 180 d, are calculated for high altitudes as well as for nearly all of Scandinavia. High altitudes in Scandinavia as well as the regions north of the Arctic Circle show growing seasons under $150 \mathrm{~d}$.

One of the warmest years in Europe in the period 1961-1998 was the year 1990. The length of the growing season in this year can be seen in Fig. 4. In most parts of the British Isles, France, Belgium, southwest
Europe, The Netherlands and the Rhine Valley in Germany, the growing season lasted over 220 and up to 240 d. In southeast Europe, nearly all of Germany, western Poland, the Czech Republic, Austria, Switzerland, Slovakia and Hungary, the length of the growing season was between 200 and 220 d in 1990, whereas eastern Europe and the northern Baltic Sea region show lengths of 180 to $200 \mathrm{~d}$. Shorter growing seasons were only found in northern Scandinavia and at altitudes over $800 \mathrm{~m}$.

Averaged over all of Europe, a lengthening of the growing season by $12 \mathrm{~d}$ compared to the long-term mean was found for 1990, whereas a shortening of the growing season by $10 \mathrm{~d}$ was found for the cool year 1970. Further maps of selected phenophases (longterm means, trends, single years) can be seen on our homepage (http://www.agrar.hu-berlin.de/pflanzenbau/ agrarmet/). 


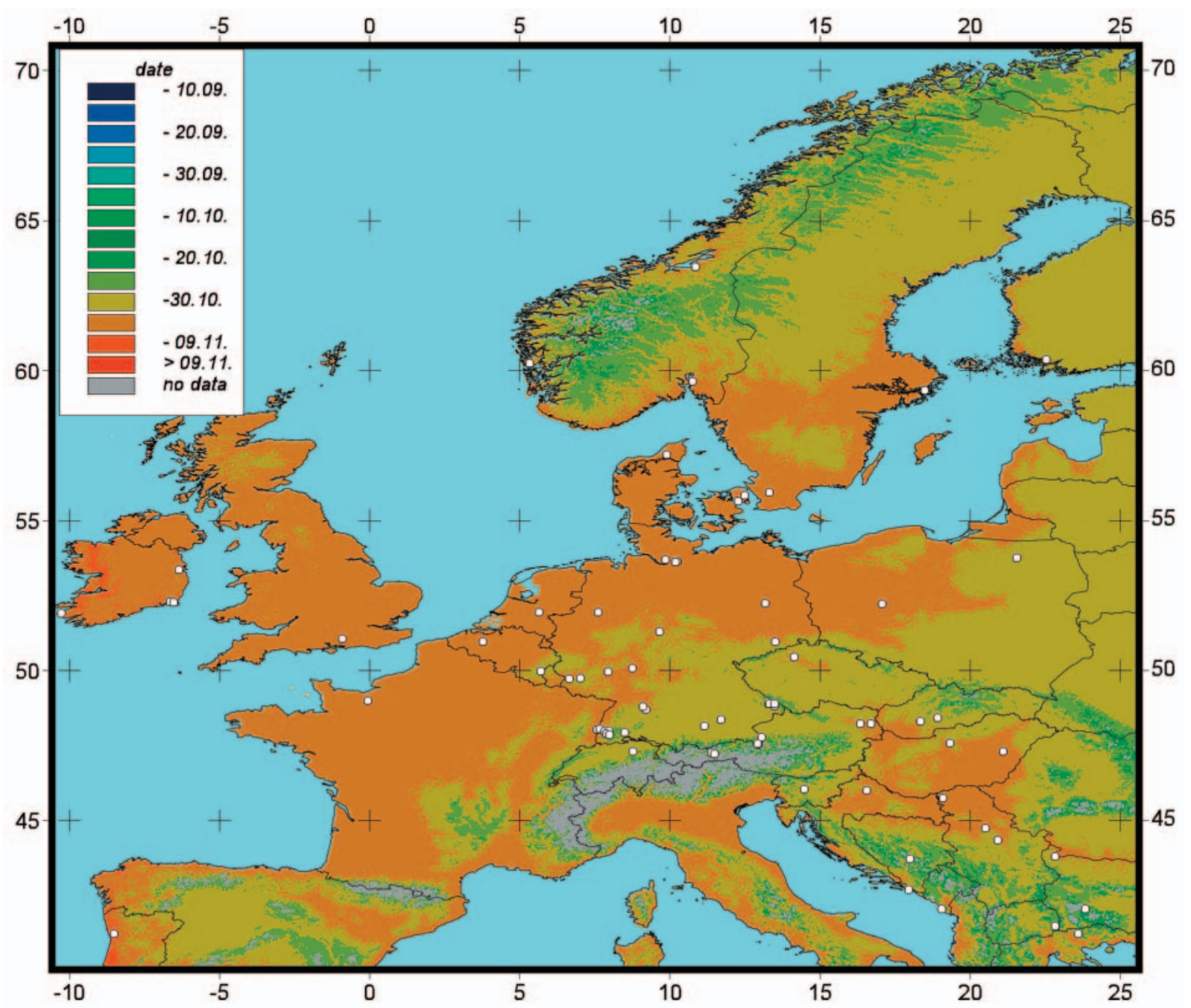

Fig. 2. Average end of the growing season in Europe for the period 1961-1998

\section{DISCUSSION}

Averaged over the spring phenophases (BO Ribes alpinum and Betula pubescens, B Prunus avium, M Picea abies and Pinus silvestris), leaf unfolding, mayshoot and flowering begin $3 \mathrm{~d}$ later per $100 \mathrm{~m}$ altitude, $0.6 \mathrm{~d}$ later per $100 \mathrm{~km}$ from west to east and $2.4 \mathrm{~d}$ later per $100 \mathrm{~km}$ from south to north (Table 1). The dependences of the starting dates of the summer phenophases (B Robinia pseudoacaccia and Sambucus nigra, F Prunus avium and $S$. nigra) are strong for altitude and latitude, whereas there is no significant dependence on longitude. Autumn phenophases show only slight dependences on altitude, longitude and latitude.

All maps presented show annual timings of phenophases based on the geographical factors altitude, longitude and latitude. Other geographical factors, e.g. those described by Sachweh \& Würländer (1995), could not be included in the mapping of the annual timings of phenophases because of a lack of geographical data, e.g. the 'building density index'. The difference in the mean starting dates between rural areas and areas with high building densities was calculated by Rötzer et al. (2000) and Sachweh \& Rötzer (1997), who found differences of 2 to $4 \mathrm{~d}$ for spring phenophases based on values from different national networks. For the IPGs we found the beginning of the spring phenophases to occur 2 to $5 \mathrm{~d}$ earlier in urban areas, while autumn phenophases began 3 to $4 \mathrm{~d}$ later.

Exposure and inclination could not be considered when mapping the annual timings of phenophases for Europe because of the scale of the maps; however, phenophases have been shown to begin $14 \mathrm{~d}$ earlier or later depending on exposure and inclination (Kreeb 1954, Schnelle 1955, Chen 1994). 


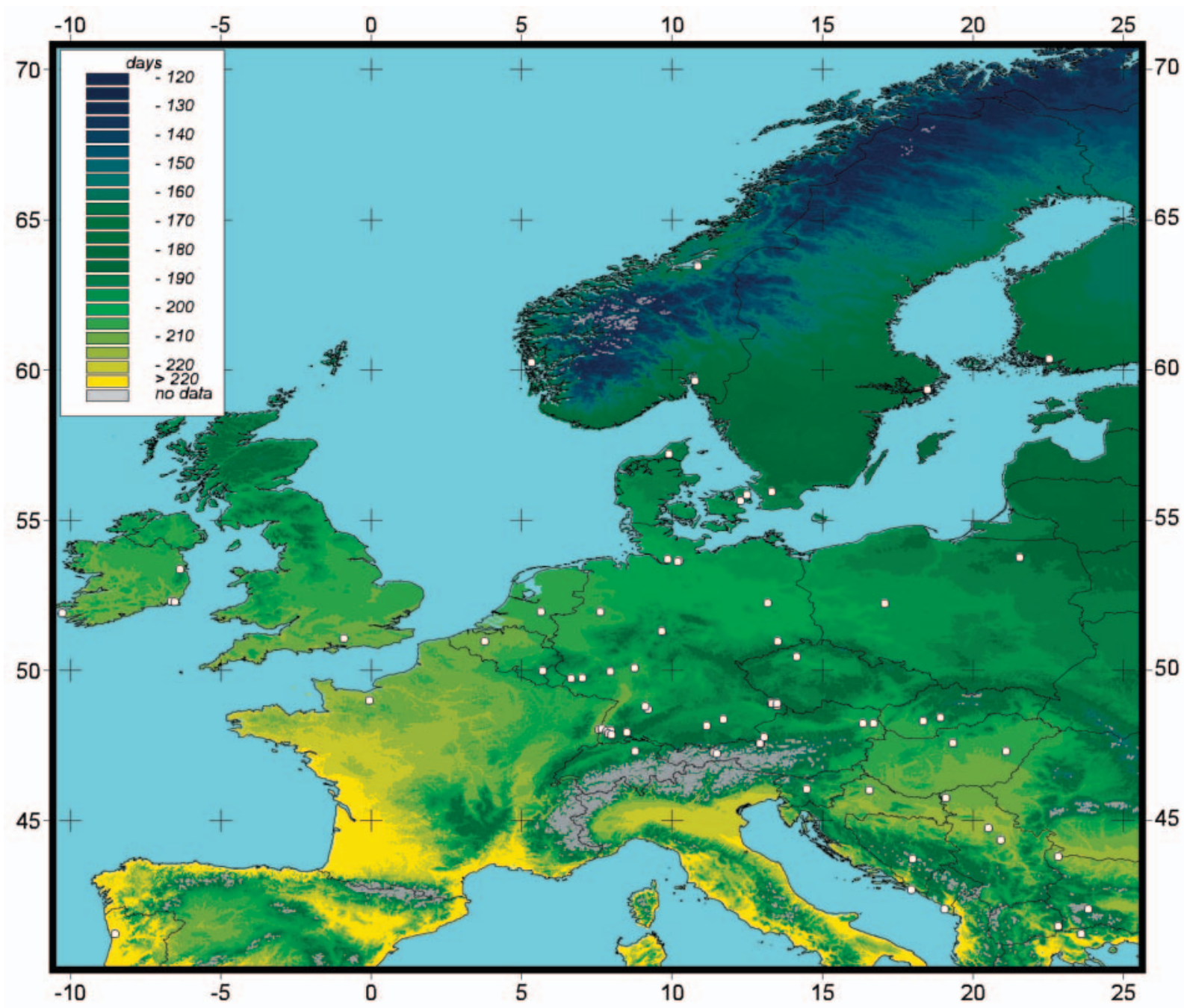

Fig. 3. Average length of the growing season in Europe for the period 1961-1998

The influence of the different varieties of a plant species can equal up to $12 \mathrm{~d}$, depending on site, plant species and phenophase (Table 2). On average the varieties of Picea abies (mayshoot) and Fagus silvatica (leaf unfolding) show differences of $6 \mathrm{~d}$, while the differences between the varieties of Prunus avium (beginning of flowering) and Quercus robur (leaf unfolding) were much smaller ( 0 and $1 \mathrm{~d}$, respectively).

In the phenological maps shown here, the influence of variety could be excluded because the IPG data are based on observations of genetically identical plants. All the other influences listed above are not included in the phenological maps. However, as the goodness of fit values (up to $97 \%$ ) and the standard deviations (2.8 to 8.2 d) show, altitude, longitude and latitude are the most relevant influences. Only autumn phenophases and thus the end of the growing season have smaller goodness of fit values, which means there are influences from other unknown factors.
In addition to the regression coefficients of altitude, longitude and latitude based on the phenophases of IPG 61-98, Table 3 shows the coefficients of DWD 51-80 and DWD 61-90, computed for Bavaria from observations made by the German Weather Service (Deutscher Wetterdienst, DWD) for the periods 1951-1980 (Rötzer 1996) and 1961-1990 (Rötzer et al. 1997). Despite the fact that these results are from different periods and from different data sets, they correspond well with ours. Nearly all regression coefficients are on the same level. With the exception of the beginning of flowering of Tilia cordata (a summer phenophase), the differences between the altitude coefficients of the different data sets are smaller than $0.6 \mathrm{~d}$ per $100 \mathrm{~m}$. The mean altitude coefficient of the IPG phenophases was $3.5 \mathrm{~d}$ per $100 \mathrm{~m}$, which corresponds well with those of DWD 51-80 (3.3 d per $100 \mathrm{~m}$ ) and DWD 61-90 (3.4 d per $100 \mathrm{~m}$ ). Overall, no relationship between the phenophases and the longitude coeffi- 
Table 2. Averaged differences (d) between the annual timings of mayshoot (M), beginning of flowering (B) and leaf-unfolding (BO) of 2 varieties of Picea abies ('F' and 'S'), Prunus avium ('B' and 'L'), Fagus silvatica (' $\mathrm{H}^{\prime}$ and 'D'), and Quercus robur ('W' and 'B') at different International Phenological Gardens (IPGs) for the period 1961 to1998

\begin{tabular}{|c|c|c|c|c|c|}
\hline IPG no. & $\begin{array}{l}\mathrm{M} \\
\text { (Nor }\end{array}$ & $\begin{array}{l}\text { Picea abies } \\
\text { (way spruce) }\end{array}$ & $\begin{array}{l}\text { B Prunus avium } \\
\text { (wild cherry) }\end{array}$ & $\begin{array}{l}\text { BO Fagus silvatica } \\
\text { (common beech) }\end{array}$ & $\begin{array}{l}\text { BO Quercus robur } \\
\text { (common oak) }\end{array}$ \\
\hline 2 & Bergen (Norway) & 5 & 7 & 5 & \\
\hline 3 & Oslo (Norway) & 3 & 3 & 2 & \\
\hline 5 & Stockholm (Sweden) & 3 & 2 & & \\
\hline 12 & Aalborg (Denmark) & 11 & 6 & & \\
\hline 14 & Wexford (Ireland) & 3 & -3 & 9 & \\
\hline 18 & Gent (Belgium) & 4 & -2 & 3 & 0 \\
\hline 44 & Mikolajki (Poland) & 3 & -1 & & \\
\hline 23 & Muenchen (Germany) & 7 & 3 & 7 & -1 \\
\hline 37 & Freising (Germany) & 3 & 1 & 5 & 3 \\
\hline 46 & Zurich (Switzerland) & 12 & 0 & 9 & \\
\hline 50 & Vienna (Austria) & 8 & 0 & & \\
\hline 52 & Zvolen (Slovakia) & 4 & 1 & 6 & 0 \\
\hline 56 & Zagreb (Croatia) & 8 & 0 & 8 & 3 \\
\hline 57 & Sombor (Serbia) & 12 & -1 & 1 & \\
\hline 61 & Belgrade (Serbia) & 4 & 0 & -1 & \\
\hline 55 & Ljubljana (Slovenia) & 9 & 1 & 8 & \\
\hline 65 & Saloniki (Greece) & 7 & & & \\
\hline 58 & Sarajevo (Bosnia-Herzegowina) & 6 & 1 & 0 & 1 \\
\hline \multirow[t]{2}{*}{45} & Porto (Portugal) & -1 & & & \\
\hline & Mean & 6 & 0 & 6 & 1 \\
\hline
\end{tabular}

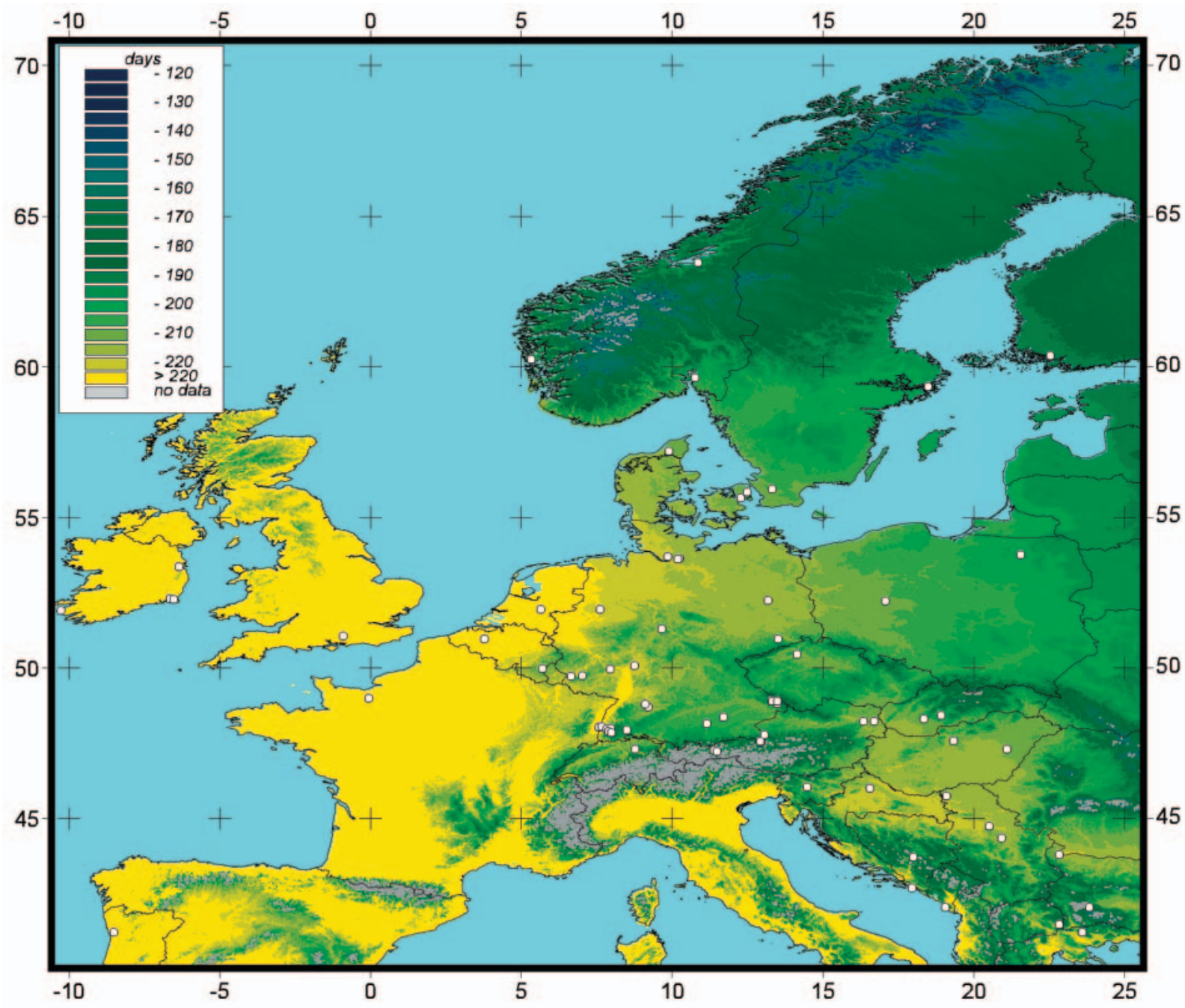

Fig. 4. Length of the growing season in Europe of the year 1990 
Table 3. Regression coefficients of the altitude $\left(a_{Z}\right)$, longitude $\left(a_{X}\right)$ and latitude $\left(a_{Y}\right)$ for different phenophases (B: beginning of flowering, M: mayshoot, F: first ripe fruits) based on observations made at the IPGs for the period 1961-1998 (IPG 61-98) and by the German Weather Service for the periods 1951-1980 (DWD 51-80) and 1961-1990 (DWD 61-90) (Rötzer 1996, Rötzer et al. 1997)

\begin{tabular}{|c|c|c|c|c|c|c|c|c|c|c|}
\hline \multirow[t]{3}{*}{ Plant } & \multirow[t]{3}{*}{ Phase } & \multicolumn{3}{|c|}{$a_{z}(\mathrm{~d} / 100 \mathrm{~m})$} & \multicolumn{3}{|c|}{$a_{\mathrm{X}}(\mathrm{d} / 100 \mathrm{~km})$} & \multicolumn{3}{|c|}{$a_{\mathrm{V}}(\mathrm{d} / 100 \mathrm{~km})$} \\
\hline & & IPG & DWD & DWD & IPG & DWD & DWD & IPG & DWD & DWD \\
\hline & & $61-98$ & $51-80$ & $61-90$ & $61-98$ & $51-80$ & $61-90$ & $61-98$ & $51-80$ & $61-90$ \\
\hline Prunus avium (wild cherry) & B & 2.9 & 3.3 & & & 0.7 & 1.2 & & 2.5 & 3.3 \\
\hline Sambucus nigra (common elder) & B & 3.4 & 3.4 & 3.5 & 0.0 & 0.0 & 0.0 & 2.8 & 2.7 & 3.2 \\
\hline Sambucus nigra (common elder) & F & 2.9 & 3.1 & & 0.0 & 0.0 & & 3.6 & 1.3 & \\
\hline Prunus avium (wild cherry) & $\mathrm{F}$ & 3.7 & 3.4 & 4.2 & 0.0 & 0.0 & -1.3 & 3.2 & 0.0 & 0.7 \\
\hline Picea abies (Norway spruce) & M & 3.1 & & 2.5 & 0.4 & & 0.0 & 2.0 & & 2.2 \\
\hline Tilia cordata (small-leaved lime) & $\mathrm{B}$ & 5.2 & 3.2 & & 0.0 & 0.0 & & 2.0 & 2.0 & \\
\hline Mean & & 3.5 & 3.3 & 3.4 & - & - & - & 2.7 & 1.9 & 2.0 \\
\hline
\end{tabular}

cients was found by the different data sets. The latitude coefficients show similar results for the different data sets. Except for the phenophase first ripe fruits for Sambucus nigra and Prunus, all differences were lower than $0.8 \mathrm{~d}$ per $100 \mathrm{~m}$. On average all timings of IPG phenophases show a dependence on latitude of $2.7 \mathrm{~d}$ per $100 \mathrm{~km}$, which compares well with the values of DWD 51-80 (1.9 d per $100 \mathrm{~km}$ ) and DWD 61-90 $(2.0 \mathrm{~d}$ per $100 \mathrm{~km})$. It must be taken into account, however, that the regression coefficients of DWD 51-80 and DWD 61-90 were calculated for south German stations only.

Schnelle (1955), König \& Mayer (1988) and Chen (1994) computed a beginning of spring phenophases that was 1 to $3 \mathrm{~d}$ later per $100 \mathrm{~m}$ greater altitude for different regions of Europe. The beginning of first spring phenophase found by Wimmenauer (1897; cited in Schnelle 1955) for Germany to be 2.5 d later from south to north and $0.7 \mathrm{~d}$ later from west to east corresponds well with our results.

When comparing a map of the beginning of flowering of Sambucus nigra based on the DWD 61-90 data (Rötzer et al. 1997) to the same map based on IPG data, we can see similar structures, which means similar annual timings. However, 2 main differences are present: First, there is a difference of about 2 to $4 \mathrm{~d}$ between the 2 maps, which is probably due to the period covered by the IPG data being warmer (Chmielewski $\&$ Rötzer 2001). Second, the regression equation for the DWD 61-90 map includes-besides the regressors altitude, longitude and latitude - the building density index; it thus includes an earlier flowering in areas with high building densities, i.e. urban areas.

The maps of flowering of Robinia pseudoacaccia presented by Walkovszky (1998) for the periods 1951-1980 and 1983-1994 correspond well with the IPG map for the period 1961-1998.

Kramer (1996) found leaf unfolding for Fagus silvatica to advance by $3.6 \mathrm{~d}$ per ${ }^{\circ} \mathrm{C}$, and Beaubien \& Free- land (2000) calculated spring flowering to advance by $4 \mathrm{~d}$ per ${ }^{\circ} \mathrm{C}$. Taking into account that temperature decreases $0.65^{\circ} \mathrm{C}$ per $100 \mathrm{~m}$ altitude, we found-based on the regression coefficients for altitude-leaf unfolding for $F$. silvatica to advance by $3.2 \mathrm{~d}$ per ${ }^{\circ} \mathrm{C}$ and the spring phenophase beginning of flowering of Prunus avium to advance by $4.5 \mathrm{~d}$ per ${ }^{\circ} \mathrm{C}$. While Walkovszky (1998) found that Robinia pseudoaccacia flowers $7 \mathrm{~d}$ earlier per ${ }^{\circ} \mathrm{C}$, we calculated $7.1 \mathrm{~d}$ per ${ }^{\circ} \mathrm{C}$ for the same phenophase based on the regression coefficient for altitude.

The phenological maps of Europe shown here are the first published raster maps that show the annual timings of phenological phases in detail. They form the basis for future maps considering further geographical factors such as building density index, land use, exposure and inclination.

Acknowledgements. The authors thank all observers of the International Phenological Gardens in Europe for their honorary and valuable work in the last $40 \mathrm{yr}$. This study was financially supported by the German Bundesministerium für Bildung und Forschung (BMBF-project 01LA 98501).

\section{LITERATURE CITED}

Beaubien EG, Freeland HJ (2000) Spring phenology trends in Alberta, Canada: links to ocean tempearture. Int J Biometeorol 44:53-59

Chen X (1994) Untersuchung zur zeitlich-räumlichen Ähnlichkeit von phänologischen und klimatologischen Parametern in Westdeutschland und zum Einfluß geooekologischer Faktoren auf die phänologische Entwicklung im Gebiet des Taunus. Ber Dtsch Wetterdienst 189, Offenbach am Main

Chmielewski FM (1996) The international phenological gardens across Europe. Present state and perspectives. Phenol Seasonality 1:19-23

Chmielewksi FM, Rötzer T (2001) Response of tree phenology to climate change across Europe. Agric For Meteorol 108: $101-112$ 
König C, Mayer H (1988) Phänologie und Frühjahrswitterung unter dem Aspekt 'Neuartige Waldschäden'. Fachtagung 'Umweltmeteorologie' München 1988; Wiss Mitt Univ München, Meteorol Inst 61

Kramer K (1996) Phenology and growth of European trees in relation to climate change. Thesis, Landbouw Universiteit Wageningen

Kreeb K (1954) Phänologische Untersuchungen auf kleinem Raum. Meteorol Rundschau 7(5/6):95-100

Lieth H, Radford JS (1971) Phenology, resource management and synagraphic computer mapping. BioScience 21(2): $62-70$

Rötzer T (1996) Neuartige Karten der Phaenologie und des Wasserhaushalts von Bayern unter Beruecksichtigung moeglicher kuenftiger Klimaverhaeltnisse. PhD thesis, Technical University of Munich

Rötzer T, Würländer W, Häckel H (1997) Agrar- und Umweltklimatologischer Atlas von Bayern. Deutscher Wetter- dienst, Weihenstephan

Rötzer T, Wittenzeller M, Häckel H, Nekovar J (2000) Phenology in central Europe-differences and trends of springphenophases in urban and rural areas. Int J Biometeorol 44:60-67

Sachweh M, Rötzer T (1997) Climatic change effects on phenological phases in Southern Germany. Proc 14th Int Congr Biometeorol 2:226-233

Sachweh M, Würländer R (1995) Derivation of land form parameters for climatic mapping. GIS 8(4):65-71

Schnelle F (1955) Pflanzen-Phaenologie. Akad Verlagsgesellschaft, Leipzig

Schwarz MD, Reed BC (1999) Surface phenology and satellite sensor-derived onset of greenness: an initial comparison. Remote Sensing 20:3451-3459

Walkovszky A (1998) Changes in phenology of the locust tree (Robinia pseudoacacia) in Hungary. Int J Biometeorol 41: $155-160$

Submitted: October 20, 2000; Accepted: December 22, 2000 Proofs received from author(s): July 20, 2001
Editorial responsibility: Gerd Esser, Gießen, Germany 